\title{
S18 Fig
}
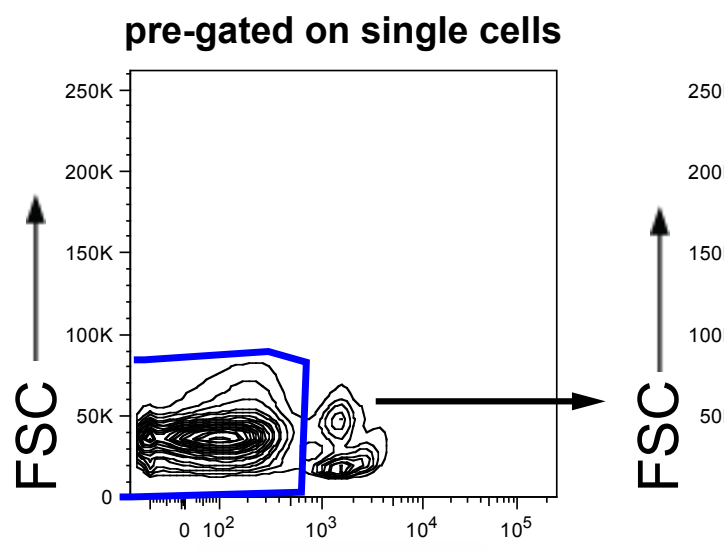

live, single cells

dump-, live, single cells

Live/dead
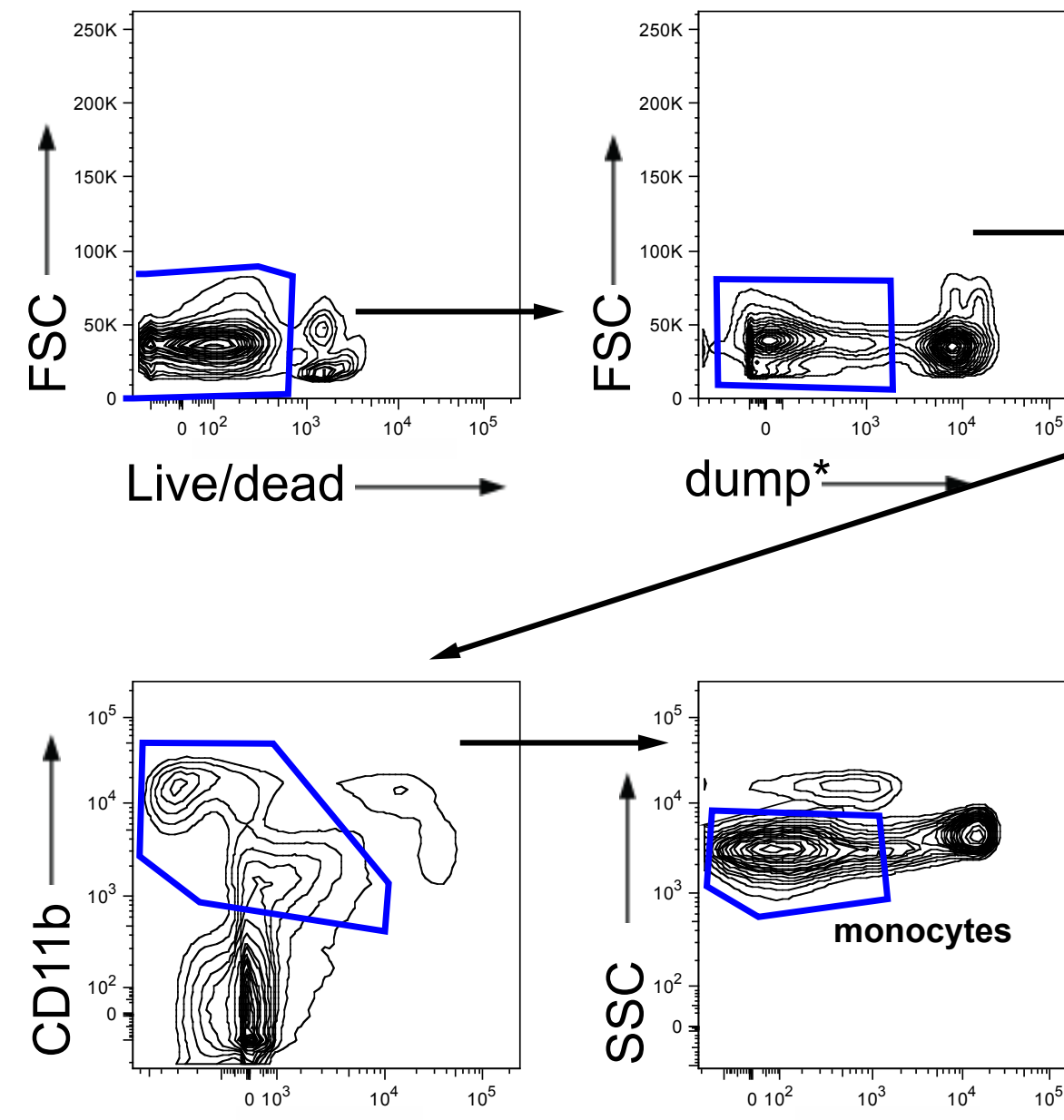

CD11c
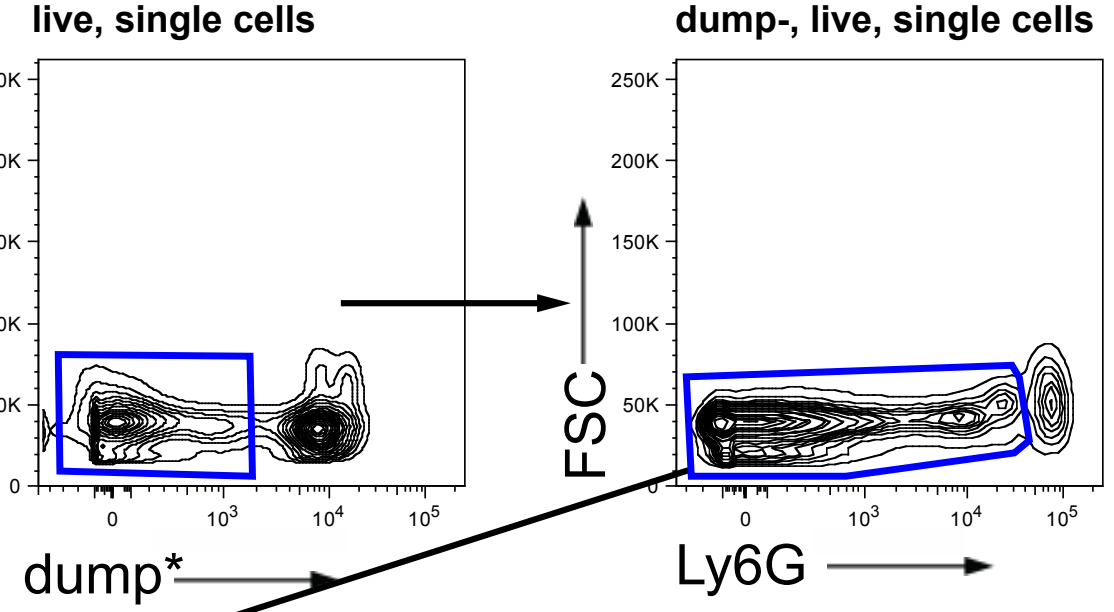

*dump: CD3, B220, NK1.1 